\title{
Woodloverness As a Pathway to Civilization Connected with Nature
}

\author{
İlker USTA* \\ Hacettepe University, Department of Wood Products Industrial Engineering, Beytepe, Ankara, Turkey
}

How to cite: Usta, İ. (2020). Woodloverness As a Pathway to Civilization Connected with Nature. J. Anatolian Env. and Anim. Sciences, 5(5), 802-806. Atıf yapmak için: Usta, İ. (2020). Doğayla Bağlantılı Medeniyete Giden Bir Yol Olarak Ahşapseverlik. Anadolu Çev. ve Hay. Dergisi, 5(5), $802-806$.

Abstract: Woodloverness, although is a vast subject that has been well known throughout the world for a long time in terms of learning based on experiences that emerge with its reflections in every phase of life with its behavioural dimension that integrates attitudes and behaviours and combines feelings and thoughts, is a term that has been named and defined almost very recently in the field of wood science and technology with the focus of woodlover approach with its inherentness that complements people whose geography is far from each other by keeping them together around the same purpose in terms of being a harmonious part of nature, and is a universal phenomenon that embraces all humanity. In a more general sense, woodloverness, in Usta's words (Usta, 2019), is a thematic issue that contributes to the development of civilization and plays an important role in the progress of humanity and is considered in the focus of the woodlover approach that aims to integrate human with nature. Obviously, with its deep and comprehensive presence, woodloverness is an interdisciplinary phenomenon that stands out clearly in the development of civilization by integrating with nature in the company of science and technology, together with art and literature, and it is a preliminary reinforcer of the effort to identify with nature and the environment, which constitute the essence of all humanity with its cultural dimension. In this study, woodloverness is presented as a deep and comprehensive phenomenon that provides endless benefits to humans through the integration of nature on the way to civilization, focusing on the woodlover approach.

Keywords: Civilization, human-nature interactions, wood, woodlover approach, woodloverness.

\section{Doğayla Bağlantılı Medeniyete Giden Bir Yol Olarak Ahşapseverlik}

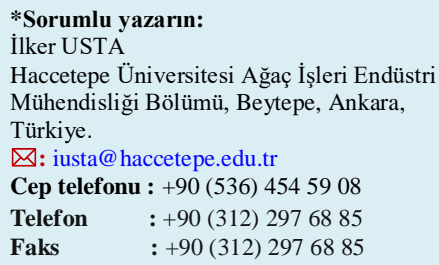

Öz: Ahşapseverlik; deneyimlere dayalı öğrenme uyarınca hem tutum ve davranışları bütünleştiren hem de duygu ve düşünceleri birleştiren davranış boyutu ile hayatın her evresinde yansımalarıyla ortaya çıkan uzun zamandır dünya çapında bilinen geniş bir konu olmasına rağmen, ahşap bilimi ve teknolojisi alanında neredeyse çok yakın zamanda isimlendirilip tanımlanmış bir terim olup coğrafyası birbirinden uzak insanları ahşapsever yaklaşım odağında doğanın uyumlu bir parçası olma açısından aynı amaç çerçevesinde bir arada tutarak tamamlayan doğası ile tüm insanlığı kucaklayan evrensel bir olgudur. Daha genel anlamda, Usta'nın deyimiyle (Usta, 2019), ahşapseverlik; medeniyetin gelişmesine katkı sağlayan ve insanlığın ilerlemesinde önemli rol oynayan tematik bir konudur ve insanı doğayla bütünleştirmeyi amaçlayan ahşapsever yaklaşım odağında ele alınmaktadır. Açıkçası, ahşapseverlik, derin ve kapsamlı varlığı ile bilim ve teknoloji eşliğinde, sanat ve edebiyatla birlikte doğa ile bütünleşerek medeniyetin gelişmesinde net bir şekilde öne çıkan disiplinlerarası bir kavramdır ve kültürel boyutu ile tüm insanlığın özünü oluşturan doğa ve çevre ile özdeşleşme çabasının öncelikli pekiştiricisidir. Bu çalışmada, ahşapseverlik, ahşapsever yaklaşım esas alınarak doğayla bütünleşmek suretiyle gerçekleşen uygarlaşma sürecinde, insanlara sonsuz fayda sağlayan derin ve kapsamlı bir olgu olarak sunulmuştur.

Anahtar kelimeler: Ahșap, ahșapsever yaklașım, ahșapseverlik, insan-doğa etkileșimi, medeniyet. 


\section{INTRODUCTION}

Wood, which is a natural and organic material obtained from trees with its fibrous and porous structure, is the oldest and widely used material in the history of humanity with a very wide area of use in reference to its easy processing and has played a major role in the development of civilization and the progress of humanity. It is clear that the use of wood alone or indirectly with other materials in order to meet the needs and fulfill the requirements as a sustainable natural material is closely related to its unique material properties in terms of its anatomical structure, chemical composition, physical properties, and mechanical properties. At this point, despite the fact that the breadth and depth of the presence of wood in almost every area of life have been revealed through the ongoing researches since a relatively long time, and significant contributions have been made to the enrichment of the knowledge about wood, these studies are not sufficient in number and scope in terms of fully recognizing wood and have not yet been completed. And here, while the material properties of wood, as well as its existential dimension affecting all of life, are being studied comprehensively with an inexhaustible effort, like an inquisitive and resourceful traveler sailing to the wind in unstable weather conditions on the shore of a vast ocean, it has been attempted to show how important wood is to the communities all across the world from the past to the present as a material and an entity, in the light of some special facts or theories, due to its unlimited availability. In this context, woodloverness, as a privileged theory reinforced with the principle of causality on the basis of woodlover approach, emerges as an important phenomenon that clearly expresses that wood is a valuable object embracing the whole universe and all humanity. However, although woodloverness is a phenomenon known to all societies since the beginning of human history, it is still a privileged subject waiting to be defined in detail and in depth. Therefore, in this particular study, which is provided basically by benefiting from the articles of Usta (2019) titled "A fact of woodloverness on the basis of woodlover approach" and "Woodloverness", the theory of woodloverness is presented with annotations and conceptual characterizations centered on the woodlover approach to allow for understanding in a holistic and indepth manner. From this point of view, this study is very highly important with its content, because the case of "woodloverness", which is the main reinforcement of the subject of "woodlover approach", will be explained in greater detail here as a holistic and complementary new theory by associating causality with many issues in terms of its content that directs life and its effect that unites people. In this regard, presenting woodloverness, which focuses on universality with its deep and comprehensive content, as a multi-faceted theory, will open a new horizon in the field of wood science and technology. It is also envisaged that the explanations made here will shed light on all humanity as an indicator of the universality of wood. And hence, the scope of this study is twofold: firstly, to prepare good explanations with the intention of drawing attention to the phenomenon of woodloverness on the basis of woodlover approach, and to create awareness about this special issue in the worldwide public opinion with the field of wood science and technology, and secondly to explain and promote in a way that will benefit everyone, which is a global situation that makes globalization continuous. Therefore, this study has a special content that will allow the woodlover approach to come to the fore with a conscious awareness with a new perspective..

\section{THE NOTION OF WOODLOVERNESS}

It is obvious that wood, which is a fascinating component of life and an indispensable part of life with its unlimited variety of products that integrate with daily life practices, is the only material standing by people in the ordinary course of life and is a valuable entity that embraces the whole society. In this respect, it is certain that the endless efforts that put wood into life with a wide variety of product types are realized with the concept of woodloverness that focuses on the woodlover approach. Truly, considering the fact that wood is a common value of humanity as a means of intercultural interaction that connects the past to the present and the future with the numerous benefits that has provided to humanity as a material throughout history, it is clearly seen that all the activities carried out with the concept of woodloverness on the basis of woodlover approach are in harmony with the essence of creativity and the mental process of innovation and in close relationship with each other within an integrated fiction.

Based on innovation and creativity throughout history, the latent aspect of woodloverness, which has always emphasized the entrepreneurial attitude and behaviour accompanied by wood, has brought it to a very special position that is easily perceived and immediately noticed in the design of the unlimited variety of products or applications that are persistently put forward with a woodlover approach. Ultimately, woodloverness, which is a common theory accompanied by a woodlover approach, is a pure reality that allows the civilization process, which facilitates life by integrating with nature, and enables people to live comfortably, by consciously using wood, which is a typical reflection of nature, with creative and innovative solutions. From this perspective, woodloverness is not only a certain term that has a 
relatively long validity in the field of wood science and technology, but also is a very special assumption that has guided evaluation for underlying either prospective or retrospective studies of welfare and quality of life in social and technical literatures in order to provide scientific evidences that can be properly acquired by experimental and observational investigations. In this context, a fact of woodloverness that is evaluated within the framework of woodlover approach, which is a universal phenomenon focused on the theme of giving importance to nature and people by taking care of both nature and people, by using wood supplied from trees as a sustainable and renewable natural material correctly and effectively, includes a progressive and enlightenment perspective that prioritizes optimism and positive thinking in the focus of the science and technology of wood, which has made great contributions to the development of humanity and the progress of civilization, because the phenomenon of woodloverness has a detailed content that embraces all humanity without any distinction, representing the individual and social reality with its internality prioritizing the individual and society, and contributing to the development of civilization by nature and human adaptation.

In the light of these explanations, it is an indisputable reality that woodloverness, which focuses on the woodlover approach, is a fundamental phenomenon that coexists with humans, and it is undoubtedly certain that woodloverness has a thematic content that can be comprehensively explained by comparable definitions in terms of its effect on the ordinary course of life by making causality associations with all theories and practices that are intertwined with life in one way or another. In essence, "woodloverness" is endless efforts based on making meaning of life and beautifying it with unlimited freedom by overcoming difficulties by designing wood from a very wide angle and using it in the best possible way in terms of many different applications and various types of products in order to improve daily life. If a broader definition is made, "woodloverness", which is a common attitude of those who realize the beauty and importance of living with an indispensable passion for wood, a natural and organic material obtained from trees, by valuing nature as an indicator of human dignity, is a multidimensional phenomenon that adds value to human life and makes life meaningful, due to the many successful and effective solutions of wood that make daily life easier and more enjoyable. At this point, considering the possible marginalization of wood in the understanding and interpretation of current discussions and suggestions for the evaluation of wood as an important material and a valuable entity on the basis the woodlover approach, the phenomenon of woodloverness can be spoken as a subjective concept that can be evaluated in detail by directly or indirectly associating with theories or concepts from almost all disciplines.

In fact, it is clear that woodloverness, which is an indicator of the woodlover approach that integrates wood, which is always in harmony with humans, as a constructive or supportive material into life, is a significant phenomenon that can be conceptualized with its unique position in the development of civilization and the progress of humanity, and is influenced by the descriptions revealed by the knowledge about wood as a material and as an entity due to a vast array of opportunities for sustainable solutions what it provides for people around the world since ancient times. Therefore, the fact that wood is a versatile and functional material and also a valuable entity for people from similar or different cultures throughout history has a great effect on the comprehensive presentation of the subject of woodloverness, which is an important and multidimensional phenomenon that is intertwined with the concepts of authenticity and cultural existentialism and expressionism on the basis of woodlover approach that focuses on universality, as a theory that has a unique internal consistency and adequate explanatory power. Of course, in the company of this reality, it is obvious that activities or researches aiming to reveal wood as a material and an entity with a woodlover approach will allow the efforts to reconcile woodloverness with almost all existing areas with a wider perspective.

Since it is absolute that a life without wood can never exist, the realization of woodlover efforts with an unprecedented enthusiasm and deep commitment that envisage the continuous inclusion of wood into life in terms of an unlimited variety of products and applications will make a great contribution to the consolidation of the notion of woodloverness. This is because woodlover efforts are at the heart of woodloverness, which is a dominant phenomenon in both the development and spread of civilization in the company of nature and the progress of humanity, and such that these indescribable efforts, which make wood stand out with its content that directs life, both create the common perception of all people in the focus of a life integrated with wood and support the adoption and internalization of woodloverness as a global phenomenon. All these woodlover endeavors in the context of woodloverness involve various types of causal propositions realized with the woodlover approach that places wood at the center of universal thought, and contain a number of unique considerations to clarify the existence of wood as a material and as an entity. Ultimately, as we all get to know and learn about wood, it will become easier and more common to associate almost any theme or subject or concept directly or indirectly with the phenomenon of woodloverness. 
If we make an inference according to the above explanations, it is obvious that the woodlover approach, which forms an inseparable integrity with environmental awareness, includes innovative and creative actions to increase the quality of life, and hence it is essential to constantly examine the whole existence of wood from a multi-dimensional perspective in order to consolidate woodloverness as a general acceptance. A lot of things can be said about this issue, but what we particularly draw attention to here is the necessity to unearth the content of wood that provides countless benefits to all humanity by examining the properties of wood as an important material and as a valuable entity. Frankly, based on a woodlover approach with a holistic perspective that focuses on sustainability, wood, which is defined as a versatile and functional material in terms of its anatomical structure, chemical composition, physical properties and mechanical properties, is considered to be a universal entity that affects people's feelings, thoughts, attitudes and behaviours as a distinguished intercultural interaction tool. Therefore, the introductory and informative activities foreseen on wood, a natural and organic material used alone or in combination with other materials to meet the various needs and different requirements that arise in the ordinary course of daily life, are about wood that has existed since the beginning of human history, contains an undeniable reality that it will be very useful in terms of creating an individual and social consciousness and awareness and gaining strong insight. From this viewpoint, because consciousness of woodloverness would not shaped without awareness of the technical, social and cultural aspects of wood that have been brought to light with extensive experience and scientific research methods, it is inevitable to examine the whole possible existence of wood as an extraordinary material and a considerable entity in depth and comprehensively with the woodlover approach.

Since knowledge is built with science, it is essential to demonstrate scientifically all the peculiar properties of wood that have been noticed by experience from past to present in order to be associated with almost all matters related to life and to be established causality link with all possible disciplines in terms of evaluating and interpreting the phenomenon of woodloverness with a broad knowledge. For this, when an assessment of the basic assumptions about wood is made, it is obvious that the following truths known to everyone in a definite reality are prioritized as a final determination:

1. Wood, which is a natural and organic material obtained from trees, is healthy with its fibrous and porous structure and is a versatile and functional material that is used in different ways for different purposes in daily life with its easy processability.
2. Wood, which is a renewable natural resource since it is obtained from trees as a reflection of nature with sustainable forestry activities, offers almost endless options thanks to its anatomical structure and chemical composition, and physical properties and mechanical properties.

3. The science and technology of wood has made wood a considerable material used directly or indirectly in meeting the needs and requirements that arise in the normal course of daily life.

4. Wood is not only a material, but also a valuable entity that influences people's attitudes and behaviours, feelings and thoughts, and their outlook on life, and is also an important object that contributes to people's communication with each other and is of course a unique tool in intercultural interaction.

5. Wood, which is a good and useful material that has always stood by people since the beginning of history with its naturalness, aesthetic appeal, characteristic feature that is convenient to provide unlimited solutions, and functionality, becomes strong and durable, even almost indestructible when prepared in accordance with the foreseen usage conditions.

6. Wood, a natural and organic material that can be used almost everywhere with its superior material properties, is an outstanding material that has played a major role in the development and spread of civilization, and therefore the contribution of wood to the progress of humanity to the present day is an indisputable extent.

7. Wood, which is a unique material and a perfect entity in accordance with its versatility and functionality, is intertwined with almost all thoughts based on living as an integral part with nature in unity and harmony, and is integrated with almost all approaches to make sense of life accompanied by the principles that guide life.

8. Wood is an incredible material that can be used alone or in combination with other materials in almost all arrangements and adaptations that make life easier, and it is a transcendent entity that makes people behave in the same or similar way in a positive thought.

To summarize, all the above explanations clearly show how important the efforts made with the woodlover approach are in evaluating woodloverness as a pathway to civilization connected with nature, and firmly emphasize that we should realize how much wood is actually present in our lives as a material and an entity. As a result, the effects of wood on our lives contain an undeniable reality, and woodloverness, which focuses on wood, which is a widely used material with activities carried out with a woodlover approach, is an important phenomenon with its multi-dimensional interiority. 


\section{CONCLUSION}

It is clear that woodloverness is a deep and comprehensive phenomenon that guides life with an unlimited number of products and applications that are constantly realized with the woodlover approach that focuses on wood and can be associated with almost all disciplines. In this regard, since wood is a universal material that provides numerous benefits to people directly or indirectly, either alone or in combination with other materials, in meeting the needs and requirements that arise in the ordinary course of daily life, and since it is an international entity that embraces everyone by contributing to the living in the same or similar attitudes, behaviours, emotions and thoughts with a positive thinking, it is normal and inevitable that the phenomenon of woodloverness, which focuses on wood as a material and as an entity, with its continuous and discrete quantities and features that can be transformed into benefits, is defined in both concrete and abstract contexts and evaluated in universal dimensions with its unique content, referring to the woodlover approach. In this framework, defining woodloverness as a multi-dimensional phenomenon with a woodlover approach is only possible by placing wood in the center as a thematic element in terms of individual and social awareness with its unique subjectivity.

In accordance with these explanations, it is the basic starting point to make a common determination and inference about wood as a material and an entity in order to make a reconciliation between the phenomenon of woodloverness and other possible phenomena with causeeffect relation, and it is necessary to make this beginning very accurately in order to successfully realize the theoretical explanation towards woodloverness. Accordingly, in the context of determining the phenomenon of woodloverness in general terms, the known determinations about wood in accordance with the woodlover approach can be emphasized as follows:

a. Wood is an inexhaustible renewable natural material derived from trees grown with sustainable forestry activities as a unique reflection of nature with extraordinary and immense beauty.

b. Wood is a universal material that provides numerous benefits to all people directly or indirectly, either alone or in combination with other materials, in meeting the needs and requirements that arise in the ordinary course of daily life.

c. Wood, which is a common material that meets the needs and requirements of people with its versatility and functionality, is a marvelous material that stands out clearly in the relationship between technology and civilization with its superior material properties. d. Wood is an outstanding material that has a great share in the development and spread of civilization and the progress of humanity by reinforcing intercultural interaction.

e. Considering globalization and cultural sharing and empathy, wood, which is an important intercultural interaction tool, is a valuable entity that affects people's feelings, thoughts, attitudes and behaviours, referring to its natural and organic structure with its fibrous and porous structure.

f. Wood, as a material and an entity, is fully or partially integrated with almost all phenomena that shape life and make sense of life with its versatile and functional aspects.

g. Wood has a comprehensive identity, whose properties have been continuously researched throughout history and recognized by experience from past to present, such that the knowledge of wood, which is a natural and organic material that contains sustainability in its nature, is constantly renewed by extensive experience and vast research.

h. Wood is an excellent material that incorporates creativity and innovative thinking and highlights an entrepreneurial perspective, and is the most influential entity in the entire universe that stimulates emotions.

Consequently, in order to define woodloverness as a unique phenomenon in the focus of wood as an extraordinary material and a wonderful entity, it is possible to make comprehensive evaluations by looking at a broader perspective with a woodlover approach. Lastly, it is obvious that woodloverness is a deep-rooted phenomenon with its holistic identity that continues its existence from past to future with its life-guiding effect and its presence that sheds light for all humanity.

\section{ACKNOWLEDGMENTS}

This paper was presented at the International Forest Products Congress [ORENKO 2020] held on 23-26 September 2020, Trabzon, Turkey, and selected for publication in the Journal of Anatolian Environmental and Animal Sciences.

\section{REFERENCES}

Usta, I. (2019). A Fact of Woodloverness on the basis of Woodlover Approach. Eurasian Journal of Social and Economic Research, 6(8), 179-195.

Usta, I. (2019). Woodloverness. Mesleki Bilimler Dergisi, 8(2), 92-115. 